\title{
Article \\ Lung Cancer Characteristics in the World Trade Center Environmental Health Center
}

\author{
Nedim Durmus 1,2, Sultan Pehlivan 1,2, Yian Zhang 2,3, Yongzhao Shao 2,3,4,5, Alan A. Arslan 2,3,4,5,6, \\ Rachel Corona ${ }^{2}$, Ian Henderson ${ }^{1}$, Daniel H. Sterman ${ }^{1}$ and Joan Reibman 1,2,4,*
}

1 Department of Medicine, Division of Pulmonary Medicine, School of Medicine (SOM), New York University, New York, NY 10016, USA; Nedim.Durmus@nyulangone.org (N.D.); sultan.pehlivan@nyulangone.org (S.P.); ian.henderson@nyulangone.org (I.H.); daniel.sterman@nyulangone.org (D.H.S.)

2 World Trade Center Environmental Health Center, NYC H+HC, New York, NY 10016, USA; yian.zhang@nyulangone.org (Y.Z.); yongzhao.shao@nyulangone.org (Y.S.); alan.arslan@nyulangone.org (A.A.A.); rachel.corona@downstate.edu (R.C.)

3 Department of Population Health, Division of Biostatistics, School of Medicine (SOM), New York University, New York, NY 10016, USA

4 Department of Environmental Medicine, School of Medicine (SOM), New York University, New York, NY 10016, USA

5 NYU Perlmutter Comprehensive Cancer Center, New York, NY 10016, USA

6 Department of Obstetrics and Gynecology, School of Medicine (SOM), New York University, New York, NY 10016, USA

Citation: Durmus, N.; Pehlivan, S. Zhang, Y.; Shao, Y.; Arslan, A.A.; Corona, R.; Henderson, I.; Sterman, D.H.; Reibman, J. Lung Cancer Characteristics in the World Trade Center Environmental Health Center. Int. J. Environ. Res. Public Health 2021, 18, 2689. https://doi.org/10.3390/ ijerph18052689

Academic Editors: James Cone, Abeliz Santiago-Colon and Roberto Lucchini

Received: 31 December 2020 Accepted: 26 February 2021 Published: 7 March 2021

Publisher's Note: MDPI stays neutral with regard to jurisdictional claims in published maps and institutional affiliations.

Copyright: (c) 2021 by the authors. Licensee MDPI, Basel, Switzerland. This article is an open access article distributed under the terms and conditions of the Creative Commons Attribution (CC BY) license (https:// creativecommons.org/licenses/by/ $4.0 /$ )
* Correspondence: joan.reibman@nyulangone.org

Abstract: The destruction of the World Trade Center (WTC) towers on 11 September 2001 resulted in acute and chronic dust and fume exposures to community members, including local workers and residents, with well-described aerodigestive adverse health effects. This study aimed to characterize lung cancer in the WTC Environmental Health Center (WTC EHC) focusing on gender and smoking history. WTC EHC patients undergo an initial evaluation that includes WTC exposure information, demographics, and tobacco use. Detailed cancer characteristics are recorded from pathology reports. As of 31 December 2019, 248 WTC EHC patients had a diagnosis of lung cancer. More patients with lung cancer were women (57\%) compared to men (43\%). Many cases ( $47 \%$ women, $51 \%$ men) reported acute dust cloud exposure. Thirty-seven percent of lung cancer cases with available smoking history were never-smokers ( $\leq 1$ pack-years) and $42 \%$ had a $\leq 5$ pack-year history. The median age of cancer diagnosis in never-smoking women was 61 years compared to 66 years in men. Adenocarcinoma was more common in never-smokers compared to ever-smokers (72\% vs. $65 \%$ ) and in women compared to men $(70 \%$ vs. $65 \%)$. We provide an initial description of lung cancers in local community members with documented exposure to the WTC dust and fumes.

Keywords: WTC Environmental Health Center; World Trade Center; September 11th; lung cancer; cancer characteristics

\section{Introduction}

The destruction of the World Trade Center (WTC) towers on 11 September 2001 exposed local workers, residents, and those passing by (community members), as well as those involved in rescue and recovery, to potentially extensive inhalation of the WTC dust and fumes [1-3]. The WTC Environmental Health Center (WTC EHC) was created in response to local community requests in the years after 11 September. With the advent of the James Zadroga 11 September Health and Compensation Act of 2010 (H.R. 847), the WTC EHC was included as the Center of Excellence for community members (defined as "Survivors") [4]. Patients self-refer into this program and under law, inclusion requires defined WTC dust/fume exposure and the presence of a "Certifiable condition" [2,4]. Virtually all cancers were added as "Certifiable conditions" in 2012 [5]. 
We, as well as other researchers, demonstrated that WTC acute and chronic exposures are significantly associated with many adverse health conditions in adults and children, particularly aerodigestive disorders [2,6-15]. Increased cancer rates (e.g., thyroid cancer, prostate cancer) and decreased rates for lung cancer have been described in the WTC Responders and WTC Survivors [16-20], with numerous cancers included in the list of WTC-related diseases in 2012 [5]. Numerous known carcinogens have been described in the WTC dust and fumes. These have been well-summarized in review papers and include asbestos, silica, heavy metals, as well as polycyclic aromatic hydrocarbons, polychlorinated biphenyls, polychlorinated dibenzofurans, and dioxins. In addition, benzene, and other volatile organic compounds were reported from jet fuels [3,21-26]. Because of the inhalation of dust and fumes containing these carcinogens, as well as the identification of persistent particles thought to be derived from WTC dust in the lungs of responders as well as community members $[27,28]$, the risk of lung cancer in exposed populations has been a major concern. Animal studies have suggested potential for carcinogenicity since WTC dust exposure in mice is associated with inflammation, oxidative stress, and epigenetic changes in the lung [29]. Although lung cancer is a leading cause of cancer deaths in the general population among men as well as women [30-33], the WTC literature on lung cancer in women is limited particularly because WTC responders are mostly men. As such, there is an important knowledge gap about cancers, including lung cancer in women with WTC dust/fume exposure.

Previously, we described overall cancer characteristics in the WTC EHC [34]. Lung cancer is the third most frequent cancer in our community population $(9 \%)$ and the second most frequent cancer in women (11\%). In contrast to responder studies, about half of WTC EHC enrollees are women. In addition to information on WTC exposure information, the WTC EHC database has detailed data on tobacco smoking, a well-known risk factor for lung cancer.

The objective of this paper is to provide descriptive lung cancer characteristics among the WTC "Survivors," including an examination of potential differences by gender and history of tobacco use. We report a case series of the lung cancers identified in the WTC EHC as of 31 December 2019 and the characteristics of these cancers. To our knowledge, this is the first study reporting detailed lung cancer characteristics in the WTC-exposed population of local community members.

\section{Methods}

\subsection{Clinical and Lung Cancer Characteristics in Patients in the WTC EHC}

Patients self-refer into the WTC EHC under rules now defined by the federal government $[4,35]$. These rules include specific geographic boundaries (roughly south of Houston Street and some western areas of Brooklyn) and time periods (from 11 September 2001 to 31 July 2002) during which a community member can be considered exposed. In addition, the member must have a "certifiable" condition. Members are included in the WTC EHC clinical database which includes basic demographic information, WTC dust and other exposures collected using detailed questionnaires, and the clinical characteristics of the WTC-certifiable conditions [4]. In this study, we classified exposure to the WTC dust on 11 September 2001 as dust cloud exposure and also classified exposure groups as clean-up workers, residents, students, local workers, and others. Detailed data on WTC exposure and other important exposures, such as smoking history, are also captured, allowing for analyses of the impact of smoking and other factors. Tobacco use was defined as never ( $\leq 1$ pack-year; $p-y)$, former ( $>1 \mathrm{p}-\mathrm{y}$, stopped) and current ( $>1 \mathrm{p}-\mathrm{y}$, continue) at enrollment. However, there were too few current smokers among lung cancer patients $(n=14)$ to make a statistical comparison, and thus we merged the groups of former $(n=113)$ and current $(n=14)$ smokers and categorized tobacco use among lung cancer patients as never-smokers, those reporting a $\leq 1 \mathrm{p}-\mathrm{y}(n=76)$ and ever-smokers, those reporting $>1 \mathrm{p}-\mathrm{y}(n=127)$. Tobacco use information was not available for lung cancer cases from one clinical site of the WTC EHC $(n=45)$. 


\subsection{Lung Cancer Characteristics}

The cancer characteristics of lung cancer patients are derived from the newly developed WTC EHC Pan-Cancer Database (PCDB), which was created to capture information on all cancer types in the WTC EHC and to interface with the current WTC EHC clinical databases [36]. We use REDCap as a secure Federal Information Security Modernization Act and Health Insurance Portability and Accountability Act -compliant environment to support data capture for the WTC EHC PCDB [37,38]. The three main domains of the database include patient demographics, cancer characteristics, and cancer biomarker information [36].

We obtained information on lung cancer characteristics from the WTC EHC PCDB, which includes data extracted from pathology reports and available medical records. All available information are carefully reviewed by a pathologist and clinicians at the WTC EHC. Lung cancer characteristics such as age at diagnosis, anatomic location of tumor (ICD-10 classification), tumor size, tumor grade, tumor histology (ICD-O-3 code), and TNM (Tumor, Node, Metastases) stage are recorded for each cancer case. Second primary tumors, defined according the International Association of Cancer Registries and International Agency for Research on Cancer (IACR/IARC) criteria are also recorded [39]. Importantly, the location of the medical facility where the biopsies and surgeries were performed is included in the database in order to enable future tumor sample procurement.

Subjects were asked to provide their informed consent for inclusion before they participated in the study. The study was conducted in accordance with the Declaration of Helsinki, and the protocol was approved by the New York University School of Medicine Institutional Review Board (IRB number: i06-1). Patients with lung cancer were analyzed after removal of personal identifiers with IRB approval to review de-identified data (IRB number: i06-1_MOD49). Documentation of consent to be re-contacted is included for subsequent studies.

\subsection{Data Analysis}

Descriptive statistics were used to summarize WTC exposure and demographic characteristics of lung cancer patients including median and range for continuous variables and counts and percentages for binary or categorical variables. Tumor characteristics were compared by sex and smoking history using chi-square tests and Fisher's exact test for categorical variables and Mann-Whitney test for continuous variables. Distribution of age of diagnosis for every 5-year period stratified by sex and smoking history was summarized using bar graphs. Statistical software $R-3.6 .3$ was utilized to conduct statistical analyses.

\section{Results}

\subsection{Participants}

We identified 11,038 patients who were enrolled in the WTC EHC between May 2002 and 31 December 2019. Among them, 2840 patients had any type of cancer including 248 with a primary lung cancer diagnosis. Fifteen patients had more than one primary lung cancer diagnosis. Lung cancer was the second most frequent cancer (after breast cancer) in women accounting for $11 \%$ of female cancers, whereas it was the third most frequent cancer (after prostate cancer and lymphomas) in men, accounting for $7 \%$ of all male cancers patients in the WTC EHC population [34].

\subsection{WTC Exposure and Demographic Characteristic in Lung Cancer Patients in the WTC EHC} Stratified by Smoking History

Tobacco smoking is a major risk factor for lung cancers. We summarize basic exposure and demographic characteristics of lung cancer patients categorized by smoking status in Table 1. Of the 248 patients with lung cancer in the WTC EHC, 203 patients had available smoking history, 119 were women (59\%), and $84(41 \%)$ were men. Thirty-seven percent $(n=76)$ were never-smokers $(\leq 1 \mathrm{p}-\mathrm{y})$ whereas $63 \%(n=127)$ were ever-smokers $(>1 \mathrm{p}-\mathrm{y})$. The median age of lung cancer diagnosis was 62 for never-smokers (range 38-88) and 65 years for ever-smokers 
(range 34-89). Ever smokers had diverse race/ethnicity composition with 56\% White, 23\% Asian, and $14 \%$ Black or African American. Distribution of race/ethnicity varied by smoking status with a high proportion of Asians (46\%) who were never-smokers and many White $(66 \%)$ who were ever-smokers. Many patients had a low-income (56\%) and 38\% had an educational status of high school or less. Nearly half of the patients $(49 \%)$ were exposed to the dust cloud on 11 September 2001 (Table 1).

Table 1. Characteristics of lung cancer patients in the World Trade Center Environmental Health Center (WTC EHC) $(n=$ 203) with smoking history in the WTC EHC.

\begin{tabular}{|c|c|c|c|c|c|}
\hline & & \multicolumn{4}{|c|}{ Smoking } \\
\hline & & Overall & Never ( $\leq 1$ p-y) & Ever (>1 p-y) & $p$ \\
\hline$n$ & & 203 & 76 & 127 & \\
\hline \multirow{2}{*}{ Gender, $n(\%)$} & Female & $119(58.6)$ & $58(76.3)$ & $61(48.0)$ & \multirow{2}{*}{$<0.001$} \\
\hline & Male & $84(41.4)$ & $18(23.7)$ & $66(52.0)$ & \\
\hline $\begin{array}{l}\text { Age on 9/11 (years) } \\
\text { (median (range)) }\end{array}$ & & $50.7(25.3,74.0)$ & $49.7(27.5,71.6)$ & $51.9(25.3,74.0)$ & 0.21 \\
\hline $\begin{array}{l}\text { Age of diagnosis (years) } \\
\text { (median (range)) }\end{array}$ & & $64(34,8)$ & $62(38,88)$ & $65(34,89)$ & 0.07 \\
\hline \multirow{4}{*}{ Race/Ethnicity, $n(\%)$} & White & $110(55.8)$ & $29(39.2)$ & $81(65.9)$ & \multirow{4}{*}{$<0.001$} \\
\hline & Black & $27(13.7)$ & $9(12.2)$ & $18(14.6)$ & \\
\hline & Asian & $46(23.3)$ & $34(45.9)$ & $12(9.8)$ & \\
\hline & Hispanic & $14(7.1)$ & $2(2.7)$ & $12(9.8)$ & \\
\hline \multirow{3}{*}{ BMI, n (\%) } & $\begin{array}{l}\text { Normal weight } \\
\qquad(<25)\end{array}$ & $56(38.6)$ & $23(50.0)$ & $33(33.3)$ & \multirow{3}{*}{0.17} \\
\hline & $\begin{array}{l}\text { Overweight } \\
(25-30)\end{array}$ & $51(35.2)$ & $13(28.3)$ & $38(38.4)$ & \\
\hline & Obese $(\geq 30)$ & $38(26.2)$ & $10(21.7)$ & $28(28.3)$ & \\
\hline \multirow{2}{*}{ Income, $n(\%)$} & $\leq \$ 30,000 /$ year & $107(56.0)$ & $45(64.3)$ & $62(51.2)$ & \multirow{2}{*}{0.09} \\
\hline & $>\$ 30,000 /$ year & $84(44.0)$ & $25(35.7)$ & $59(48.8)$ & \\
\hline \multirow{2}{*}{ Education, $n(\%)$} & High school or less & $78(38.4)$ & $32(42.1)$ & $46(36.2)$ & \multirow{2}{*}{0.46} \\
\hline & $\begin{array}{c}\text { More than high } \\
\text { school }\end{array}$ & $125(61.6)$ & $44(57.9)$ & $81(63.8)$ & \\
\hline \multirow{2}{*}{ Dust cloud, $n(\%)$} & No & $103(50.7)$ & $37(48.7)$ & $66(52.0)$ & \multirow{2}{*}{0.66} \\
\hline & Yes & $100(49.3)$ & $39(51.3)$ & $61(48.0)$ & \\
\hline \multirow{3}{*}{ Exposure category, $n(\%)$} & Worker & 115 (56.9) & $29(38.2)$ & $86(68.3)$ & \multirow{3}{*}{$<0.001$} \\
\hline & Resident & $74(36.6)$ & $44(57.9)$ & $30(23.8)$ & \\
\hline & Other & $13(6.4)$ & $3(3.9)$ & $10(7.9)$ & \\
\hline
\end{tabular}

\subsection{Lung Cancer Characteristics by Smoking History in the WTC EHC}

Overall lung cancer characteristics stratified by smoking history for the first primary lung tumor are shown in Table 2. The majority of the lung cancers $(90 \%)$ had a histologic type consistent with non-small cell carcinoma, (adenocarcinoma (71\%), squamous cell carcinoma $(10 \%)$, unidentified subtype of non-small cell carcinoma $(6 \%)$, and large cell carcinoma (1\%)). Only $2 \%$ of the cancers were small cell carcinoma and $6 \%$ were carcinoid tumors. Among all histologic types of lung cancers, $17 \%$ were well-differentiated (Grade 1), $21 \%$ were moderately-differentiated (grade 2 ) and $21 \%$ were poorly-differentiated (Grade 3 ). Although the primary cancers were distributed throughout the lung, the right upper lobe $(25 \%)$ was the most common location of primary lung cancer. Most patients had only one lesion (90\%), however $8 \%$ had two primary lesions, and $2 \%$ had three or more lesions. (Table 2). 
Table 2. Characteristics of lung cancers in the WTC Environmental Health Center with smoking history.

\begin{tabular}{|c|c|c|c|c|c|}
\hline & \multirow[b]{2}{*}{ Level } & \multicolumn{4}{|c|}{ Smoking } \\
\hline & & Overall & Never ( $\leq 1$ p-y) & Ever (>1 p-y) & $p$ \\
\hline$n$ & & 203 & 76 & 127 & \\
\hline \multirow{7}{*}{ Histology, $n(\%)$} & Adenocarcinoma & $143(70.4)$ & $60(79.0)$ & $83(65.4)$ & \multirow{7}{*}{0.02} \\
\hline & $\begin{array}{l}\text { Squamous Cell } \\
\text { Carcinoma }\end{array}$ & $24(11.8)$ & $4(5.3)$ & $20(15.6)$ & \\
\hline & Carcinoid Tumors & $13(6.4)$ & $7(9.2)$ & $6(4.7)$ & \\
\hline & $\begin{array}{l}\text { Large cell } \\
\text { Carcinoma }\end{array}$ & $3(1.5)$ & $1(1.3)$ & $2(1.6)$ & \\
\hline & $\begin{array}{l}\text { Small Cell } \\
\text { Carcinoma }\end{array}$ & $3(1.5)$ & $0(0.0)$ & $3(2.4)$ & \\
\hline & Unidentified & & & & \\
\hline & $\begin{array}{c}\text { Non-Small Cell } \\
\text { Carcinoma or } \\
\text { Unknown }\end{array}$ & $17(8.4)$ & $4(5.2)$ & $13(10.3)$ & \\
\hline \multirow{5}{*}{ Grade, $n(\%)$} & G1 & $32(15.8)$ & $14(18.4)$ & $18(14.2)$ & \multirow{5}{*}{0.77} \\
\hline & G2 & $44(21.6)$ & $16(21.1)$ & $28(22.0)$ & \\
\hline & G3 & $42(20.7)$ & $15(19.7)$ & $27(21.3)$ & \\
\hline & $\mathrm{G} 4$ & $1(0.5)$ & $0(0.0)$ & $1(0.8)$ & \\
\hline & GX or Unknown & $84(41.4)$ & $31(40.8)$ & $53(41.7)$ & \\
\hline \multirow{6}{*}{ Tumor size, $n(\%)$} & Tis & $6(2.9)$ & $5(6.6)$ & $1(0.8)$ & \multirow{6}{*}{0.21} \\
\hline & $\mathrm{T} 1$ & $88(43.4)$ & $32(42.1)$ & $56(44.2)$ & \\
\hline & $\mathrm{T} 2$ & $41(20.2)$ & $12(15.7)$ & $29(22.8)$ & \\
\hline & $\mathrm{T} 3$ & $14(6.9)$ & $4(5.3)$ & $10(7.9)$ & \\
\hline & $\mathrm{T} 4$ & $6(2.9)$ & $2(2.6)$ & $4(3.1)$ & \\
\hline & TX or Unknown & $48(23.7)$ & $21(27.7)$ & $27(21.2)$ & \\
\hline $\begin{array}{l}\text { Tumor Size in cm } \\
\text { (median (range)) }\end{array}$ & & $1.7(0.2,11.5)$ & $1.8(0.4,5.0)$ & $1.7(0.2,11.5)$ & 0.84 \\
\hline Regional Lymph & No & $110(54.2)$ & $39(51.3)$ & $71(55.9)$ & \multirow{3}{*}{0.47} \\
\hline \multirow{2}{*}{$\begin{array}{c}\text { Node Metastasis, } n \\
(\%)\end{array}$} & $\mathrm{N} 1$ & $52(25.6)$ & $17(22.4)$ & $35(27.6)$ & \\
\hline & NX or Unknown & $41(20.2)$ & $20(26.3)$ & $21(16.5)$ & \\
\hline \multirow{3}{*}{$\begin{array}{c}\text { Distant Metastasis, } \\
n(\%)\end{array}$} & M0 & $139(68.5)$ & $48(63.2)$ & $91(71.6)$ & \multirow{3}{*}{0.20} \\
\hline & $\mathrm{M} 1$ & $32(15.7)$ & $15(19.7)$ & $17(13.4)$ & \\
\hline & MX or Unknown & $32(15.8)$ & $13(17.1)$ & $19(15.0)$ & \\
\hline \multirow{6}{*}{ Stage, $n(\%)$} & 0 & $6(3.0)$ & $5(6.6)$ & $1(0.8)$ & \multirow{6}{*}{0.08} \\
\hline & I & $86(42.3)$ & $29(38.2)$ & $57(44.8)$ & \\
\hline & II & $21(10.3)$ & $7(9.2)$ & $14(11.0)$ & \\
\hline & III & $26(12.8)$ & $7(9.2)$ & $19(15.0)$ & \\
\hline & IV & $32(15.8)$ & $15(19.7)$ & $17(13.4)$ & \\
\hline & Unknown & $32(15.8)$ & $13(17.1)$ & $19(15.0)$ & \\
\hline \multirow{9}{*}{$\begin{array}{l}\text { Anatomic location, } \\
n(\%)\end{array}$} & Right upper lobe & $50(24.6)$ & $18(23.7)$ & $32(25.2)$ & \multirow{9}{*}{0.60} \\
\hline & Right middle lobe & $8(3.9)$ & $3(3.9)$ & $5(3.9)$ & \\
\hline & Right Lower Lobe & $17(8.4)$ & $10(13.2)$ & $7(5.5)$ & \\
\hline & Right unspecified & $35(17.2)$ & $14(18.4)$ & $21(16.5)$ & \\
\hline & Left upper lobe & $32(15.8)$ & $9(11.8)$ & $23(18.1)$ & \\
\hline & Left Lower Lobe & $18(8.9)$ & $6(7.9)$ & $12(9.5)$ & \\
\hline & Left unspecified & $39(19.2)$ & $15(19.8)$ & $24(18.9)$ & \\
\hline & Bilateral & $1(0.5)$ & $0(0.0)$ & $1(0.8)$ & \\
\hline & Unknown & $3(1.5)$ & $1(1.3)$ & $2(1.6)$ & \\
\hline
\end{tabular}

The median tumor size at diagnosis was $1.8 \mathrm{~cm}$ (range $0.2-11.5 \mathrm{~cm}$ ) and $42 \%$ of patients had less than $3 \mathrm{~cm}$ in greatest dimension (T1). No regional lymph node metastases were identified in $55 \%$ of the patients. Evidence of regional lymph node involvement was observed in $25 \%$ of lung cancer patients. Fifteen percent of the patients had distant metastasis at 
diagnosis. Using the TNM staging system, at the time of diagnosis, $42 \%$ of patients were Stage I, $11 \%$ were Stage II, $12 \%$ were Stage III, and 15\% were Stage IV (Table 4).

There was no significant difference in cancer characteristics stratified by smoking history except histological type. Never-smokers had a higher proportion of adenocarcinoma compared to ever-smokers (79\% and 65\%, respectively) and carcinoid tumors (9\% and $5 \%$, respectively). As expected, ever-smokers had a higher proportion of squamous cell carcinoma compared to never-smokers $(16 \%$ and $5 \%$, respectively) $(p=0.017)$ (Table 2$)$.

\subsection{Gender and Lung Cancer in the WTC EHC}

The large number of women in the WTC EHC overall and among the lung cancer patients (57\%) provided an opportunity to describe lung cancer characteristics in women and to determine potential gender differences of lung cancer characteristics among the WTC survivors. We compared characteristics of lung cancer in women vs. men (Table 3). Women in the WTC EHC with lung cancer were slightly younger on 11 September 2001 compared to men with lung cancer (median, 49.2 vs. 52.7 years respectively; $p=0.002$ ) with a higher proportion of women under age of 40 years on that date compared with men ( $52 \%$ vs. $38 \%$ respectively; $p=0.02)$. The median age of lung cancer diagnosis was 62 years for women (range 34-85) and 66 years for men (range 38-89; $p=0.002$ ). More women lung cancer patients were Black or African-American compared to men (18\% vs. $7 \%$ ) and fewer women compared to men were Hispanic ( $4 \%$ vs. $12 \%)$. There were no statistically significant differences in BMI, income, or education between female and male lung cancer patients. Many female lung cancer patients were local residents $(42 \%)$, whereas most male lung cancer patients were local workers (67\%) (Table 2). More women (41\%) were never-smokers compared to men $(17 \%, p<0.001)$ and more men $(54 \%)$ had a $\geq 5$ p-y smoking history compared to women $(26 \%,(p<0.001)$ (Table 3$)$.

\subsection{Lung Cancer Characteristics by Gender in the WTC EHC}

A number of differences in lung cancer characteristics were noted between women and men (Table 4). Differences were noted in primary tumor location, with $22 \%$ of women and $28 \%$ of men presenting with cancer in the right upper lobe $(p=0.01)$. Differences were also noted in the primary tumor size classification with more women compared to men presenting with $\mathrm{T} 1$ lesions $(46 \%$ and $37 \%$, respectively) $(p=0.006)$ and a smaller median tumor size at diagnosis in women $(1.7 \mathrm{~cm})$ compared to men $(2 \mathrm{~cm})(p=0.03)$. There were no significant differences by lymph node involvement, distant metastasis, and stage at diagnosis. Adenocarcinoma was the main histologic type in both female and male patients (75\% and $65 \%$, respectively). However, carcinoid tumors were more frequent in women compared to men ( $9 \%$ and $3 \%$, respectively), and squamous cell carcinoma was less common in women compared to men $(6 \%$ and $17 \%$, respectively, $p=0.001)$ (Table 4$)$.

Figure 1 presents the distribution of age at lung cancer diagnosis for men and women by smoking history. More than three quarters of lung cancers developed among neversmokers were in women $(76 \% ; p<0.001)$. Among never-smokers, there was a higher proportion of women than men at earlier ages of diagnosis (median age at diagnosis, 61 and 66 years, respectively). In contrast, among ever-smokers, there was a higher proportion of men than women at later ages of diagnosis (median age at diagnosis, 67 and 64 years, respectively) (Figure 1). 
Table 3. Characteristics of lung cancer patients $(n=248)$ classified by gender in the WTC EHC.

\begin{tabular}{|c|c|c|c|c|}
\hline & \multicolumn{4}{|c|}{ Sex } \\
\hline & Level & Female & Male & $p$ \\
\hline$n$ & 248 & 142 & 106 & \\
\hline $\begin{array}{c}\text { Age on } 9 / 11 \text { (median } \\
\text { (range) })\end{array}$ & & $49.2(27.5,69.4)$ & $52.7(25.3,74.0)$ & 0.002 \\
\hline $\begin{array}{l}\text { Age of diagnosis, years } \\
\text { (median (range)) }\end{array}$ & & $62(34,85)$ & $66(38,89)$ & 0.002 \\
\hline \multirow{4}{*}{ Race/Ethnicity, $n(\%)$} & Hispanic & $5(4.2)$ & $10(12.3)$ & \multirow{4}{*}{0.03} \\
\hline & White & $63(52.9)$ & $48(59.3)$ & \\
\hline & Black & $22(18.5)$ & $6(7.4)$ & \\
\hline & Asian & $29(24.4)$ & $17(21.0)$ & \\
\hline \multirow{3}{*}{ BMI, $n(\%)$} & Normal weight $(<25)$ & $40(46.0)$ & $18(29.5)$ & \multirow{3}{*}{0.09} \\
\hline & Overweight (25-30) & $25(28.7)$ & $27(44.3)$ & \\
\hline & Obese $(\geq 30)$ & $22(25.3)$ & $16(26.2)$ & \\
\hline \multirow{2}{*}{ Income, $n(\%)$} & $\leq \$ 30,000 /$ year & $69(60.0)$ & $41(51.9)$ & \multirow[b]{2}{*}{0.30} \\
\hline & $>\$ 30,000 /$ year & $46(40.0)$ & $38(48.1)$ & \\
\hline \multirow{2}{*}{ Education, $n(\%)$} & High school or less & $42(34.4)$ & 36 (42.9) & \multirow{2}{*}{0.24} \\
\hline & More than high school & $80(65.6)$ & $48(57.1)$ & \\
\hline \multirow{2}{*}{$\begin{array}{l}\text { Dust cloud exposure, } n \\
\qquad(\%)\end{array}$} & No & $64(52.5)$ & $41(48.8)$ & \multirow{2}{*}{0.67} \\
\hline & Yes & $58(47.5)$ & $43(51.2)$ & \\
\hline \multirow{4}{*}{$\begin{array}{c}\text { Exposure category, } n \\
(\%)\end{array}$} & Resident & $51(42.1)$ & $24(28.6)$ & \multirow{4}{*}{0.12} \\
\hline & Student & $4(3.3)$ & $1(1.2)$ & \\
\hline & Worker & $61(50.4)$ & $56(66.7)$ & \\
\hline & Other & $5(4.1)$ & $3(3.6)$ & \\
\hline \multirow{2}{*}{ Pack-year, $n(\%)$} & $\leq 5$ pack-year & $64(53.8)$ & $22(26.2)$ & \multirow{2}{*}{$<0.001$} \\
\hline & $>5$ packyear & $55(46.2)$ & $62(73.8)$ & \\
\hline \multirow{3}{*}{ Smoking History, $n(\%)$} & Never $(\leq 1 \mathrm{p}-\mathrm{y})$ & $58(40.8)$ & $18(17.0)$ & \multirow{3}{*}{$<0.001$} \\
\hline & $\begin{array}{c}\text { Former smoker }(>1 \mathrm{p}-\mathrm{y}, \\
\text { stopped })\end{array}$ & $53(37.3)$ & $60(56.6)$ & \\
\hline & $\begin{array}{c}\text { Current smoker ( }>1 \mathrm{p}-\mathrm{y}, \\
\text { continue) }\end{array}$ & $8(5.6)$ & $6(5.7)$ & \\
\hline
\end{tabular}


Table 4. Characteristics of lung cancers with gender classification in the WTC Environmental Health Center.

\begin{tabular}{|c|c|c|c|c|c|}
\hline & & & Sex & & \\
\hline & Level & Overall & Female & Male & $p$ \\
\hline$n$ & & 248 & 142 & 106 & \\
\hline \multirow{6}{*}{ Histology, $n(\%)$} & Adenocarcinoma & $176(71.0)$ & 107 (75.3) & $69(65.1)$ & \multirow{6}{*}{0.001} \\
\hline & $\begin{array}{l}\text { Squamous cell } \\
\text { carcinoma }\end{array}$ & $26(10.5)$ & $8(5.6)$ & $18(17.0)$ & \\
\hline & Carcinoid tumors & $16(6.5)$ & $13(9.1)$ & $3(2.8)$ & \\
\hline & $\begin{array}{l}\text { Small cell } \\
\text { carcinoma }\end{array}$ & $6(2.4)$ & $2(1.4)$ & $4(3.8)$ & \\
\hline & $\begin{array}{l}\text { Large cell } \\
\text { carcinoma }\end{array}$ & $3(1.2)$ & $1(0.7)$ & $2(1.9)$ & \\
\hline & $\begin{array}{l}\text { Unidentified } \\
\text { subtype of } \\
\text { Non-small cell } \\
\text { carcinoma or } \\
\text { unknown }\end{array}$ & $21(8.4)$ & $11(7.7)$ & $10(9.4)$ & \\
\hline \multirow{5}{*}{ Grade, $n(\%)$} & G1 & $43(17.3)$ & $30(21.1)$ & $13(12.3)$ & \multirow{5}{*}{0.23} \\
\hline & G2 & $53(21.4)$ & $30(21.1)$ & $23(21.7)$ & \\
\hline & G3 & $51(20.6)$ & $27(19.0)$ & $24(22.6)$ & \\
\hline & $\mathrm{G} 4$ & $1(0.4)$ & $0(0.0)$ & $1(0.9)$ & \\
\hline & GX or Unknown & $100(40.3)$ & $55(38.8)$ & $45(42.5)$ & \\
\hline \multirow{6}{*}{$\begin{array}{c}\text { Tumor size, TNM, } \\
n(\%)\end{array}$} & Tis & $8(3.2)$ & $8(5.6)$ & $0(0.0)$ & \multirow{6}{*}{0.006} \\
\hline & $\mathrm{T} 1$ & $105(42.3)$ & $66(46.5)$ & $39(36.8)$ & \\
\hline & $\mathrm{T} 2$ & $53(21.4)$ & $21(14.8)$ & $32(30.2)$ & \\
\hline & T3 & $16(6.5)$ & $7(5.0)$ & $9(8.5)$ & \\
\hline & $\mathrm{T} 4$ & $8(3.2)$ & $4(2.8)$ & $4(3.8)$ & \\
\hline & TX or Unknown & $58(23.4)$ & $36(25.3)$ & $22(20.7)$ & \\
\hline $\begin{array}{l}\text { Tumor size, cm } \\
\text { median (range) }\end{array}$ & & $1.8(0.2,11.5)$ & $1.7(0.4,6.5)$ & $2.0(0.2,11.5)$ & 0.03 \\
\hline \multirow{3}{*}{$\begin{array}{l}\text { Regional lymph } \\
\text { node metastasis, } n \\
(\%)\end{array}$} & No. & $136(54.8)$ & $76(53.5)$ & $60(56.6)$ & \multirow{3}{*}{0.81} \\
\hline & $\mathrm{N} 1$ & $63(25.4)$ & $37(26.1)$ & $26(24.5)$ & \\
\hline & NX or Unknown & $49(19.8)$ & $29(20.4)$ & $20(18.9)$ & \\
\hline \multirow{3}{*}{$\begin{array}{c}\text { Distant Metastasis, } \\
n(\%)\end{array}$} & M0 & $170(68.6)$ & $94(66.2)$ & $76(71.7)$ & \multirow{3}{*}{0.16} \\
\hline & $\mathrm{M} 1$ & $38(15.3)$ & $25(17.6)$ & $13(12.3)$ & \\
\hline & MX or Unknown & $40(16.1)$ & $23(16.2)$ & $17(16.0)$ & \\
\hline \multirow{6}{*}{ Stage, $n(\%)$} & 0 & $8(3.3)$ & $8(5.6)$ & $0(0.0)$ & \multirow{6}{*}{0.06} \\
\hline & $\mathrm{I}$ & $105(42.3)$ & $55(38.7)$ & $50(47.1)$ & \\
\hline & II & $27(10.9)$ & $14(9.9)$ & $13(12.3)$ & \\
\hline & III & $30(12.1)$ & $17(12.0)$ & $13(12.3)$ & \\
\hline & IV & $38(15.3)$ & $25(17.6)$ & $13(12.3)$ & \\
\hline & Unknown & $40(16.1)$ & $23(16.2)$ & $17(16.0)$ & \\
\hline \multirow{9}{*}{$\begin{array}{c}\text { Anatomic } \\
\text { Location, } n(\%)\end{array}$} & Right upper lobe & $62(25.0)$ & $32(22.5)$ & $30(28.4)$ & \multirow{9}{*}{0.01} \\
\hline & Right middle lobe & $10(4.0)$ & $8(5.6)$ & $2(1.9)$ & \\
\hline & Right lower lobe & $20(8.1)$ & $12(8.5)$ & $8(7.5)$ & \\
\hline & Right unspecified & $43(17.4)$ & $26(18.3)$ & $17(16.0)$ & \\
\hline & Left upper lobe & $38(15.3)$ & $21(14.8)$ & $17(16.0)$ & \\
\hline & Left Lower Lobe & $26(10.5)$ & $9(6.4)$ & $17(16.0)$ & \\
\hline & Left unspecified & $43(17.3)$ & $30(21.1)$ & $13(12.3)$ & \\
\hline & Bilateral & $2(0.8)$ & $0(0.0)$ & $2(1.9)$ & \\
\hline & Unknown & $4(1.6)$ & $4(2.8)$ & $0(0.0)$ & \\
\hline
\end{tabular}




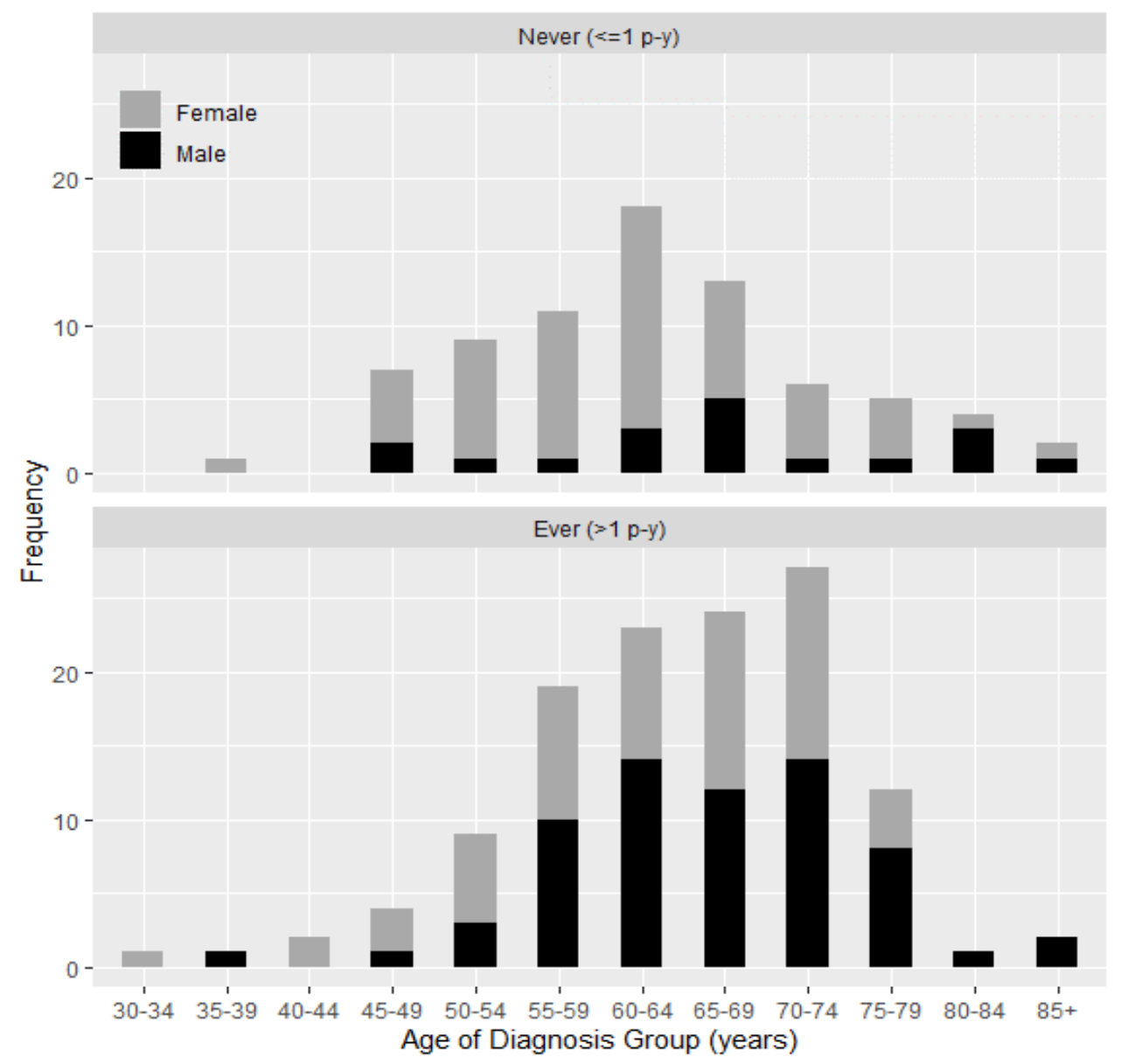

Figure 1. Distribution of age of lung cancer diagnosis in women and men by smoking history.

Distribution of age of lung cancer diagnosis in never-smokers and ever-smokers in women and men are also shown in Supplemental Figure S1 (Figure S1).

\subsection{Multiple Primary Cancers}

Sixty-four lung cancer patients had a second primary tumor. The most common second primary cancer sites included lung $(23 \%)$, thyroid $(19 \%)$, prostate $(16 \%)$, and breast $(12 \%)$ (Table S1). Among patients with two primary lung cancers, more tumors were diagnosed in the right (54\%) compared to the left lung $(43 \%)$, with two bilateral lung cancer cases. Second primary lung cancer most common characteristics were moderately differentiated $(27 \%)$, TNM stage I tumors with histology of adenocarcinoma (60\%) (Table S2).

\section{Discussion}

The destruction of the WTC towers on 11 September 2001 exposed local residents, workers, and individuals in the area to dust and fumes that included known and suspected carcinogens. Lung cancer is the leading cause of cancer death [40] in the general population, however, the characteristics of lung cancers diagnosed in local community members have not been previously described. In this first descriptive study focusing on lung cancer, we describe the characteristics of lung cancer in both women and men enrolled in the WTC EHC program.

The risk of lung cancer in those exposed to the WTC environmental disaster remains incompletely understood. In an eight-year follow-up study in the firefighters exposed to WTC dust, the lung cancer rate was lower than expected when compared to a pooled cohort of firefighters from San Francisco, Chicago, and Philadelphia [41]. Studies in responders found that the standardized incidence rate of lung cancer was similar to the general 
population [16]. Little data about the risk of lung cancer is available for WTC-exposed community members. In a 10-year follow-up study performed by the NYC Department of Health World Trade Center Registry (WTCHR), lower rates of lung cancer were identified in the civilian population [19] and a significantly reduced SIR was also observed for lung cancer among civilians during the follow-up period from 2007 through 2011 (SIR 0.69, 95\% CI 0.54-0.88) [42]. However, the required latency for lung cancer development may be longer than the data available in this time span. The civilian cohort at the WTC EHC is self-referred and thus not suited for the determination of the incidence rate of lung cancer. The objective of the current study was to describe lung cancer characteristics at WTC EHC.

Tobacco use, a known risk factor associated with lung cancer, was identified as a risk factor in the WTC EHC cohort. This finding is consistent with findings described in responders in which being a current smoker, although not a former smoker, was associated with lung cancer risk [43]. Overall, the chance that a man will develop lung cancer in his lifetime is about 1 in 15, for a woman, the risk is about 1 in 17 [44]. These numbers include both smokers and non-smokers. For smokers, the risk is much higher, while for non-smokers the risk is lower [44]. At the WTC EHC, many patients with lung cancer were never-smokers, including those with a diagnosis at a very young age. The median age of diagnosis for the never-smokers (62 years) was slightly lower, compared to the ever-smokers (65 years). The rates of acute WTC dust exposure defined as WTC dust cloud exposure was similar in ever- and never-smokers. Importantly, the median age of lung cancer diagnosis in the total lung cancer population was 64 years, nearly seven years younger than the median age of 71 years reported in national statistics [45]. Although these results may be due to early detection or selection bias since our population is self-referred and closely monitored, the young age at lung cancer diagnosis raises concern and suggests further investigation into underlying mechanisms causes.

Cancer occurrence differs by race/ethnicity with lower rates of lung cancer in Hispanics and Asians compared with Non-Hispanic Whites [45]. Many of lung cancer patients in the WTC EHC were Asian, particularly among the never-smokers. This finding may be due, in part, to selection bias within our population, which included many patients from areas in New York City with Asian communities.

The histologic distribution of cancers in the WTC EHC population varies from what has been described in the general population in which, about $13 \%$ of all lung cancers are small cell lung carcinoma, and $84 \%$ are non-small cell lung carcinoma [44]. In contrast, we identified fewer than $3 \%$ as small cell lung carcinoma. Approximately half of the lung cancers in the US are reported as adenocarcinoma [46,47], however, in our population, the majority $(71 \%)$ of tumors were adenocarcinoma, with high rates in both never- and eversmokers. We report squamous cell carcinomas in a higher proportion than that reported for the general population [48-51] and as expected, this histologic type was more common in the ever-smokers. Although rare in the general population, carcinoid tumors were identified in $6 \%$ of the WTC EHC population, and were especially high among WTCexposed women $(9 \%)$. Although direct comparison with the general population may be misleading due to the self-referral of our population, these histological findings are intriguing and require further confirmation in future studies with appropriate matched population samples.

Most of the lung cancers in the WTC EHC were identified at early stage. National statistics show much lower rates of lung cancer diagnosed at early stages with only $17 \%$ of lung cancers diagnosed at the local stage, $22 \%$ diagnosed with regional lymph node involvement and $57 \%$ of lung cancer cases having distant metastases [44,46]. However, most of our patients $(42 \%)$ were diagnosed at local stage and only $15 \%$ had distant metastasis. We observed 64 lung cancer patients (26\%) with a second primary cancer [39] which is similar to the report of second primary cancers reported in responders with thyroid cancer [18] and is higher than the data reported in the SEER database [46]. The high proportion of second primary cancers may be due to WTC exposures, genetic predisposition, increased monitoring, or a combination of these factors. The early detection and predominance of 
adenocarcinoma suggests that many of these patients may have been detected through screening or referral bias. However, the early stage and atypical histologic distribution warrants further evaluation for detection and survivor bias.

Importantly, our population with lung cancer included over 50\% women. Women with lung cancer were slightly younger than men, with lung cancer diagnoses identified in some individuals in their 30s (youngest age of lung cancer diagnosis was 34 years for women and 38 years for men). These data are consistent with findings in the U.S. population in which lung cancer, which is rare in adolescents and young adults, is higher in women in their $30 \mathrm{~s}$ compared to men [52]. We did not detect a difference between WTC dust cloud exposure on 11 September between women and men. Many more women were never-smokers compared to men, consistent with national cancer statistics [44]. Because of the self-selected nature of our cohort, it would not be appropriate to make direct comparisons between our population and general population. However, the suggested differences require further investigation.

There are several limitations of our study. The WTC EHC is a treatment program with self-referred patients. Thus, it does not provide information necessary to determine the cancer incidence rate. An important study limitation is our inability to distinguish cancers detected because of increased monitoring and screening of this population. Early lung cancer detection in our population may be due to a number of examinations, use of advanced diagnostic imaging, or medical examinations leading to early cancer detection. However, most of the cancers were self-referred, and thus not identified through the screening in the WTC EHC. Ideally, there is a need to supplement current databases with a cancer specimen bank in order to conduct association study to elucidate the possible connection between WTC exposures and lung as well as other cancers. There is also a need for a more objective WTC exposure assessment.

This study has important strengths. In contrast to the responders, the WTC EHC includes nearly $50 \%$ women, and is racially and ethnically diverse. This diversity is reflected in the patients with lung cancer, in whom more than $50 \%$ were women. The gender distribution allows for comparison of cancer rates and cancer behaviors between men and women, a study that is not possible in many responder populations. Our pan-cancer database enables us to identify patients who have agreed to be re-contacted, and have documentation of the location of biopsy specimens. Thus, we have the potential to re-call patients for future investigations and identify banked biospecimens, if necessary. The continued surveillance and follow-up of this population allows for improved understanding of the behavior of these cancers over time.

\section{Conclusions}

We provide an initial description of lung cancers in local community members with documented exposure to the WTC dust and fumes. This study sets the stage for future studies of lung cancer latency under environmental and other exposures. The large number of women with cancer, the younger age of lung cancer diagnosis, and the high frequency of adenocarcinomas and carcinoid tumors in women warrant further analysis, including a more detailed analysis using lung cancer biomarkers. The pathologic and histologic characteristics as well as cancer related biomarker information included in our WTC EHC Pan-Cancer Database will allow for future analyses of lung cancer characteristics, understanding the potential pathophysiological pathways of cancers and trends in the WTC-exposed survivors, and may provide additional information about association of environmental exposures and the development of lung and other cancers in this cohort.

Supplementary Materials: The following are available online at https:/ / www.mdpi.com/1660-460 $1 / 18 / 5 / 2689 /$ s1. Table S1. Number of multiple primary cancers with lung cancer in WTC EHC as of 31 December 2019; Table S2. Characteristics of second diagnosed primary lung cancers in WTC; Figure S1. Distribution of age of lung cancer diagnosis in never and ever smokers separated by sex.

Author Contributions: Conceptualization, J.R., N.D., A.A.A. and Y.S.; methodology, N.D., A.A.A., J.R., Y.S., Y.Z. and S.P.; software, N.D., Y.Z., S.P., R.C. and J.R.; formal analysis, Y.Z. and Y.S.; inves- 
tigation, A.A.A., N.D., S.P., Y.S., I.H., D.H.S. and J.R.; resources, Y.S. and J.R.; data curation, N.D., R.C., A.A.A. and J.R.; writing—original draft preparation, N.D., S.P., A.A.A., Y.S., D.H.S. and J.R.; writing-review and editing, N.D., A.A.A., Y.S., Y.Z., I.H., D.H.S. and J.R.; visualization, N.D. and Y.Z.; supervision, Y.S. and J.R.; project administration, N.D., A.A.A. and J.R.; funding acquisition, Y.S. and J.R. All authors have read and agreed to the published version of the manuscript.

Funding: This research was funded by CDC/NIOSH contracts 200-2017-93327 and 200-2017-93427 for the Center of Excellence at WTC EHC Clinical and Data Center. Y.S. and Y.Z. were also funded by $\mathrm{NIH} / \mathrm{NCI}$ grant 5P30CA016087 and NIH/NCI grant 1P50CA225450.

Institutional Review Board Statement: The study was conducted according to the guidelines of the Declaration of Helsinki, and approved by the institutional review board of New York University Grossman School of Medicine (IRB number: i06-1 and i06-1_MOD49).

Informed Consent Statement: Informed consent was obtained from all subjects in-volved in the study.

Data Availability Statement: The datasets are not publicly available, but de-identified and anonymized information is potentially available upon reasonable request.

Acknowledgments: We thank all the community-based organizations and community members and patients who have contributed to the success of this program. We also would like to thank Angeles Pai and Michelle Hyde for their administrative efforts in the program and Janice Levas, Kymara Kyng, Adrienne Adessi, Renee Liberty, and Susan Sosa for their efforts in the cancer care of these patients.

Conflicts of Interest: The authors declare no conflict of interest.

\section{References}

1. Reibman, J.; Lin, S.; Hwang, S.A.; Gulati, M.; Bowers, J.A.; Rogers, L.; Berger, K.I.; Hoerning, A.; Gomez, M.; Fitzgerald, E.F. The World Trade Center Residents' Respiratory Health Study: New-Onset Respiratory Symptoms and Pulmonary Function. Environ. Health Perspect. 2005, 113, 406-411. [CrossRef] [PubMed]

2. $\quad$ Reibman, J.; Liu, M.; Cheng, Q.; Liautaud, S.; Rogers, L.; Lau, S.; Berger, K.I.; Goldring, R.M.; Marmor, M.; Fernandez-Beros, M.E.; et al. Characteristics of a Residential and Working Community With Diverse Exposure to World Trade Center Dust, Gas, and Fumes. J. Occup. Environ. Med. 2009, 51, 534-541. [CrossRef] [PubMed]

3. Lippmann, M.; Cohen, M.D.; Chen, L.C. Health effects of World Trade Center (WTC) Dust: An unprecedented disaster's inadequate risk management. Crit. Rev. Toxicol. 2015, 45, 492-530. [CrossRef]

4. Reibman, J.; Levy-Carrick, N.; Miles, T.; Flynn, K.; Hughes, C.; Crane, M.; Lucchini, R.G. Destruction of the World Trade Center Towers. Lessons Learned from an Environmental Health Disaster. Ann. Am. Thorac. Soc. 2016, 13, 577-583. [CrossRef] [PubMed]

5. The World Trade Center Health Program. Regulations. Available online: https://www.cdc.gov/wtc/conditions.html (accessed on 25 December 2020).

6. Hena, K.M.; Murphy, S.; Zhang, Y.; Shao, Y.; Kazeros, A.; Reibman, J. Clinical Evaluation of Sarcoidosis in Community Members with World Trade Center Dust Exposure. Int. J. Environ. Res. Public Health 2019, 16, 1291. [CrossRef] [PubMed]

7. Kahn, L.G.; Han, X.; Koshy, T.T.; Shao, Y.; Chu, D.B.; Kannan, K.; Trasande, L. Adolescents exposed to the World Trade Center collapse have elevated serum dioxin and furan concentrations more than 12 years later. Environ. Int. 2018, 111, 268-278. [CrossRef] [PubMed]

8. Kazeros, A.; Maa, M.-T.; Patrawalla, P.; Liu, M.; Shao, Y.; Qian, M.; Turetz, M.; Parsia, S.; Caplan-Shaw, C.; Berger, K.I.; et al. Elevated Peripheral Eosinophils Are Associated with New-Onset and Persistent Wheeze and Airflow Obstruction in World Trade Center-Exposed Individuals. J. Asthma 2013, 50, 25-32. [CrossRef] [PubMed]

9. Kazeros, A.; Zhang, E.; Cheng, X.; Shao, Y.; Liu, M.; Qian, M.; Caplan-Shaw, C.; Berger, K.I.; Goldring, R.M.; Ghumman, M.; et al. Systemic Inflammation Associated With World Trade Center Dust Exposures and Airway Abnormalities in the Local Community. J. Occup. Environ. Med. 2015, 57, 610-616. [CrossRef]

10. Koshy, T.T.; Attina, T.M.; Ghassabian, A.; Gilbert, J.; Burdine, L.K.; Marmor, M.; Honda, M.; Chu, D.B.; Han, X.; Shao, Y.; et al. Serum perfluoroalkyl substances and cardiometabolic consequences in adolescents exposed to the World Trade Center disaster and a matched comparison group. Environ. Int. 2017, 109, 128-135. [CrossRef]

11. Rosen, R.; Zhu, Z.; Shao, Y.; Liu, M.; Bao, J.; Levy-Carrick, N.; Reibman, J. Longitudinal Change of PTSD Symptoms in Community Members after the World Trade Center Destruction. Int. J. Environ. Res. Public Health 2019, 16, 1215. [CrossRef]

12. Rosen, R.L.; Levy-Carrick, N.; Reibman, J.; Xu, N.; Shao, Y.; Liu, M.; Ferri, L.; Kazeros, A.; Caplan-Shaw, C.E.; Pradhan, D.R.; et al. Elevated C-reactive protein and posttraumatic stress pathology among survivors of the 9/11 World Trade Center attacks. J. Psychiatr. Res. 2017, 89, 14-21. [CrossRef]

13. Trasande, L.; Fiorino, E.K.; Attina, T.; Berger, K.; Goldring, R.; Chemtob, C.; Levy-Carrick, N.; Shao, Y.; Liu, M.; Urbina, E.; et al. Associations of World Trade Center exposures with pulmonary and cardiometabolic outcomes among children seeking care for health concerns. Sci. Total Environ. 2013, 444, 320-326. [CrossRef] [PubMed] 
14. Trasande, L.; Koshy, T.T.; Gilbert, J.; Burdine, L.K.; Attina, T.M.; Ghassabian, A.; Honda, M.; Marmor, M.; Chu, D.B.; Han, X.; et al. Serum perfluoroalkyl substances in children exposed to the world trade center disaster. Environ. Res. 2017, 154, $212-221$. [CrossRef]

15. Trasande, L.; Koshy, T.T.; Gilbert, J.; Burdine, L.K.; Marmor, M.; Han, X.; Shao, Y.; Chemtob, C.; Attina, T.M.; Urbina, E.M. Cardiometabolic profiles of adolescents and young adults exposed to the World Trade Center Disaster. Environ. Res. 2018, 160, 107-114. [CrossRef] [PubMed]

16. Li, J.; Cone, J.E.; Kahn, A.R.; Brackbill, R.M.; Farfel, M.R.; Greene, C.M.; Hadler, J.L.; Stayner, L.T.; Stellman, S.D. Association Between World Trade Center Exposure and Excess Cancer Risk. JAMA 2012, 308, 2479-2488. [CrossRef] [PubMed]

17. Moline, J.M.; Herbert, R.; Crowley, L.; Troy, K.; Hodgman, E.; Shukla, G.; Udasin, I.; Luft, B.; Wallenstein, S.; Landrigan, P.; et al. Multiple Myeloma in World Trade Center Responders: A Case Series. J. Occup. Environ. Med. 2009, 51, 896-902. [CrossRef]

18. Tuminello, S.; Van Gerwen, M.A.G.; Genden, E.; Crane, M.; Lieberman-Cribbin, W.; Taioli, E. Increased Incidence of Thyroid Cancer among World Trade Center First Responders: A Descriptive Epidemiological Assessment. Int. J. Environ. Res. Public Health 2019, 16, 1258. [CrossRef]

19. Zeig-Owens, R.; Webber, M.P.; Hall, C.B.; Schwartz, T.; Jaber, N.; Weakley, J.; Rohan, T.E.; Cohen, H.W.; Derman, O.; Aldrich, T.K.; et al. Early assessment of cancer outcomes in New York City firefighters after the 9/11 attacks: An observational cohort study. Lancet 2011, 378, 898-905. [CrossRef]

20. Lieberman-Cribbin, W.; Tuminello, S.; Gillezeau, C.; Van Gerwen, M.; Brody, R.; Mulholland, D.J.; Horton, L.; Sisco, M.; Prophete, C.; Zelikoff, J.; et al. Complementary biobank of rodent tissue samples to study the effect of World Trade Center exposure on cancer development. J. Transl. Med. 2019, 17, 342. [CrossRef]

21. Gavett, S.H. World Trade Center fine particulate matter-chemistry and toxic respiratory effects: An overview. Environ. Health Perspect. 2003, 111, 971. [CrossRef] [PubMed]

22. Lioy, P.J.; Georgopoulos, P. The Anatomy of the Exposures That Occurred around the World Trade Center Site: 9/11 and Beyond. Ann. N. Y. Acad. Sci. 2006, 1076, 54-79. [CrossRef]

23. Offenberg, J.H.; Eisenreich, S.J.; Gigliotti, C.L.; Chen, L.C.; Xiong, J.Q.; Quan, C.; Lou, X.; Zhong, M.; Gorczynski, J.; Yiin, L.-M.; et al. Persistent organic pollutants in dusts that settled indoors in lower Manhattan after September 11, 2001. J. Expo. Anal. Environ. Epidemiol. 2004, 14, 164-172. [CrossRef] [PubMed]

24. Yiin, L.-M.; Millette, J.R.; Vette, A.; Ilacqua, V.; Quan, C.; Gorczynski, J.; Kendall, M.; Chen, L.C.; Weisel, C.P.; Buckley, B.; et al. Comparisons of the Dust/Smoke Particulate that Settled Inside the Surrounding Buildings and Outside on the Streets of Southern New York City after the Collapse of the World Trade Center, September 11, 2001. J. Air Waste Manag. Assoc. 2004, 54, 515-528. [CrossRef]

25. Landrigan, P.J.; Lioy, P.J.; Thurston, G.; Berkowitz, G.; Chen, L.C.; Chillrud, S.N.; Gavett, S.H.; Georgopoulos, P.G.; Geyh, A.S.; Levin, S.; et al. Health and environmental consequences of the world trade center disaster. Environ. Health Perspect. 2004, 112, 731-739. [CrossRef] [PubMed]

26. Lioy, P.J.; Weisel, C.P.; Millette, J.R.; Eisenreich, S.; Vallero, D.; Offenberg, J.; Buckley, B.; Turpin, B.; Zhong, M.; Cohen, M.D.; et al. Characterization of the dust/smoke aerosol that settled east of the World Trade Center (WTC) in lower Manhattan after the collapse of the WTC 11 September 2001. Environ. Health Perspect. 2002, 110, 703-714. [CrossRef]

27. Boffetta, P.; Zeig-Owens, R.; Wallenstein, S.; Li, J.; Brackbill, R.; Cone, J.; Farfel, M.; Holden, W.; Lucchini, R.; Webber, M.P.; et al. Cancer in World Trade Center responders: Findings from multiple cohorts and options for future study. Am. J. Ind. Med. 2016, 59, 96-105. [CrossRef]

28. Singh, A.; Zeig-Owens, R.; Moir, W.; Hall, C.B.; Schwartz, T.; Vossbrinck, M.; Jaber, N.; Webber, M.P.; Kelly, K.J.; Ortiz, V.; et al. Estimation of Future Cancer Burden Among Rescue and Recovery Workers Exposed to the World Trade Center Disaster. JAMA Oncol. 2018, 4, 828-831. [CrossRef]

29. Sunil, V.R.; Vayas, K.N.; Fang, M.; Zarbl, H.; Massa, C.; Gow, A.J.; Cervelli, J.A.; Kipen, H.; Laumbach, R.J.; Lioy, P.J.; et al. World Trade Center (WTC) dust exposure in mice is associated with inflammation, oxidative stress and epigenetic changes in the lung. Exp. Mol. Pathol. 2017, 102, 50-58. [CrossRef]

30. Henley, S.J.; Gallaway, S.; Singh, S.D.; O’Neil, M.E.; Buchanan Lunsford, N.; Momin, B.; Richards, T.B. Lung Cancer Among Women in the United States. J. Womens Health 2018, 27, 1307-1316. [CrossRef]

31. Howlader, N.; Forjaz, G.; Mooradian, M.J.; Meza, R.; Kong, C.Y.; Cronin, K.A.; Mariotto, A.B.; Lowy, D.R.; Feuer, E.J. The Effect of Advances in Lung-Cancer Treatment on Population Mortality. N. Engl. J. Med. 2020, 383, 640-649. [CrossRef]

32. Jemal, A.; Chu, K.C.; Tarone, R.E. Recent Trends in Lung Cancer Mortality in the United States. J. Natl. Cancer Inst. 2001, 93, 277-283. [CrossRef] [PubMed]

33. Malvezzi, M.; Bosetti, C.; Rosso, T.; Bertuccio, P.; Chatenoud, L.; Levi, F.; Romano, C.; Negri, E.; La Vecchia, C. Lung cancer mortality in European men: Trends and predictions. Lung Cancer 2013, 80, 138-145. [CrossRef] [PubMed]

34. Durmus, N.; Shao, Y.; Arslan, A.A.; Zhang, Y.; Pehlivan, S.; Fernandez-Beros, M.E.; Umana, L.; Corona, R.; Smyth-Giambanco, S.; Abbott, S.A.; et al. Characteristics of Cancer Patients in the World Trade Center Environmental Health Center. Int. J. Environ. Res. Public Health 2020, 17, 7190. [CrossRef] [PubMed]

35. The World Trade Center Health Program. Regulations. Available online: https://www.cdc.gov/wtc/regulations2.html (accessed on 20 June 2020). 
36. Shao, Y.; Durmus, N.; Zhang, Y.; Pehlivan, S.; Fernandez-Beros, M.E.; Umana, L.; Corona, R.; Abbott, S.; Smyth-Giambanco, S.; Arslan, A.A.; et al. The Development of a WTC Environmental Health Center Pan-Cancer Database. Int. J. Environ. Res. Public Health 2021, 18, 1646. [CrossRef]

37. Harris, P.A.; Taylor, R.; Minor, B.L.; Elliott, V.; Fernandez, M.; O’Neal, L.; McLeod, L.; Delacqua, G.; Delacqua, F.; Kirby, J.; et al. The REDCap consortium: Building an international community of software platform partners. J. Biomed. Inform. 2019, $95,103208$. [CrossRef] [PubMed]

38. Harris, P.A.; Taylor, R.; Thielke, R.; Payne, J.; Gonzalez, N.; Conde, J.G. Research electronic data capture (REDCap)—A metadatadriven methodology and workflow process for providing translational research informatics support. J. Biomed. Inform. 2009, 42, 377-381. [CrossRef]

39. Vogt, A.; Schmid, S.; Heinimann, K.; Frick, H.; Herrmann, C.; Cerny, T.; Omlin, A. Multiple primary tumours: Challenges and approaches, a review. ESMO Open 2017, 2, e000172. [CrossRef] [PubMed]

40. American Cancer Society Cancer Statistics. Available online: https://www.cancer.org/research/cancer-facts-statistics/all-cancerfacts-figures / cancer-facts-figures-2020.html (accessed on 15 July 2020).

41. Moir, W.; Zeig-Owens, R.; Daniels, R.D.; Hall, C.B.; Webber, M.P.; Jaber, N.; Yiin, J.H.; Schwartz, T.; Liu, X.; Vossbrinck, M.; et al. Post-9/11 cancer incidence in World Trade Center-exposed New York City firefighters as compared to a pooled cohort of firefighters from San Francisco, Chicago and Philadelphia (9/11/2001-2009). Am. J. Ind. Med. 2016, 59, 722-730. [CrossRef] [PubMed]

42. Li, J.; Brackbill, R.M.; Liao, T.S.; Qiao, B.; Cone, J.E.; Farfel, M.R.; Hadler, J.L.; Kahn, A.R.; Konty, K.J.; Stayner, L.T.; et al. Ten-year cancer incidence in rescue/recovery workers and civilians exposed to the September 11, 2001 terrorist attacks on the World Trade Center. Am. J. Ind. Med. 2016, 59, 709-721. [CrossRef]

43. Shapiro, M.Z.; Wallenstein, S.R.; Dasaro, C.R.; Lucchini, R.G.; Sacks, H.S.; Teitelbaum, S.L.; Thanik, E.S.; Crane, M.A.; Harrison, D.J.; Luft, B.J.; et al. Cancer in General Responders Participating in World Trade Center Health Programs, 2003-2013. JNCI Cancer Spectr. 2020, 4, pkz090. [CrossRef] [PubMed]

44. Society, A.C. Key Cancer Statistics. Available online: https://www.cancer.org/cancer/lung-cancer/about/key-statistics.html (accessed on 15 November 2020).

45. Bethesda, M. SEER Cancer Stat Facts: Lung and Bronchus Cancer. National Cancer Institute. Available online: https://seer. cancer.gov/statfacts/html/lungb.html (accessed on 20 June 2020).

46. National Institutes of Health (NIH). Surveillance, Epidemiology, and End Results Program. Available online: https://seer.cancer. gov/index.html (accessed on 20 June 2020).

47. Travis, W.D.; Brambilla, E.; Noguchi, M.; Nicholson, A.G.; Geisinger, K.R.; Yatabe, Y.; Beer, D.G.; Powell, C.A.; Riely, G.J.; Van Schil, P.E.; et al. International Association for the Study of Lung Cancer/American Thoracic Society/European Respiratory Society International Multidisciplinary Classification of Lung Adenocarcinoma. J. Thorac. Oncol. 2011, 6, 244-285. [CrossRef] [PubMed]

48. Inamura, K. Lung cancer: Understanding its molecular pathology and the 2015 WHO classification. Front. Oncol. 2017, 7, 193. [CrossRef] [PubMed]

49. Boelens, M.C.; van den Berg, A.; Fehrmann, R.S.; Geerlings, M.; de Jong, W.K.; te Meerman, G.J.; Sietsma, H.; Timens, W.; Postma, D.S.; Groen, H.J. Current smoking-specific gene expression signature in normal bronchial epithelium is enhanced in squamous cell lung cancer. J. Pathol. 2009, 218, 182-191. [CrossRef] [PubMed]

50. De Stefani, E.; Boffetta, P.; Ronco, A.L.; Brennan, P.; Correa, P.; Deneo-Pellegrini, H.; Gutiérrez, L.P.; Mendilaharsu, M. Squamous and small cell carcinomas of the lung: Similarities and differences concerning the role of tobacco smoking. Lung Cancer 2005, 47, 1-8. [CrossRef] [PubMed]

51. Molina, J.R.; Yang, P.; Cassivi, S.D.; Schild, S.E.; Adjei, A.A. Non-Small Cell Lung Cancer: Epidemiology, Risk Factors, Treatment, and Survivorship. Mayo Clin. Proc. 2008, 83, 584-594. [CrossRef]

52. Jemal, A.; Miller, K.D.; Ma, J.; Siegel, R.L.; Fedewa, S.A.; Islami, F.; Devesa, S.S.; Thun, M.J. Higher Lung Cancer Incidence in Young Women Than Young Men in the United States. N. Engl. J. Med. 2018, 378, 1999-2009. [CrossRef] [PubMed] 